\title{
PEMANFAATAN GIS (GEOGRAPHIC INFORMATION SYSTEM) UNTUK PEMETAAN VERIFIKASI SISIP DAN POKOK PADA PERKEBUNAN KELAPA SAWIT DI KABUPATEN KUTAI BARAT KALIMANTAN TIMUR
}

\section{Utilization of GIS (Geographic Information System) for Mapping of Insert and Main Verification on Oil Palm Plantation in West Kutai Regency, East Kalimantan}

\author{
Bayu Firdaus Muslim*, Mochammad Munir \\ Jurusan Tanah, Fakultas Pertanian, Universitas Brawijaya, Jl. Veteran no 1 Malang, 65145 \\ *Penulis korespondensi: bayufirdaus597@gmail.com
}

\begin{abstract}
Verification of oil palm plants is done to cross check with census data on the number of plants to find out the number of oil palm plants in each. Unfortunately the company still has difficulty detecting the amount of palm oil in each block. One effort to overcome this problem is to use GIS (Geographic Information System). The purpose of this study was to determine the effect and differences in the use of photogrammetric methods with the waypoint method, the role of GIS (Geographic Information System) and determine the number of oil palm trees to be planted in the blocks in Afdeling I and Afdeling IV. This research through the preparation stage by preparing a sub-block map and flight plan, data collection stage by collecting aerial photo data, waypoint, block SHP, information on block area, planting year information and initial basic information on oil palm, the data processing stage using the mosaicking approach on the Agisoft PhotoScan Propessional application, waypoint conversion with Global Mapper and overlaying aerial photos with a waypoint with ArcMap 10.3. The results showed that the waypoint using GPS had higher accuracy compared to aerial photography and had an effect on the overlay results at the planned waypoint distance with the initial principal palm oil object. GIS is useful for processing aerial photo data and waypoints from GPS, and can speed up side verification. The plan is to insert in the B37 Block as many as 462 principal, B38 Block as many as 928 principal, B39 Block as many as 1,611 principal, B40 Block 351 principal, Block D29 1,063 principal, D30 Block 1,085, A53a Block 2,665 principal, A55a Block 539 subjects, C55 Block as many as 371, C56 Block as many as 510 principal, D55 Block as many as 157 principal, D56 Block as many as 375 principal, D57 Block as many as 1,561 and Block D59 with 1,431 .
\end{abstract}

Keywords : aerial photography, Geographic Information System, verification, waypoint

\section{Pendahuluan}

Pemanfaatan teknologi dan informasi merupakan hal yang tepat untuk memberikan informasi yang akurat. Peran teknologi GIS (Geographic Information System) mulai banyak dimanfaatkan kesemua bidang, salah satunya yaitu di perkebunan kelapa sawit. Pemanfaatan Sistem Informasi Geografis sangat membantu dan memiliki peran yang sangat penting, mulai dari pengelolaan kebun, mengetahui potensi lahan sampai monitoring perkembangan, perancanaan kebun dan verifikasi tanaman kelapa sawit (Sugianto, 2010). Verifikasi tanaman kelapa sawit dilakukan untuk cross check dengan data sensus jumlah tanaman dimana untuk mengetahui jumlah tanaman kelapa sawit dalam tiap blok yang sesuai 
dengan standar perusahaan yang telah ditetapkan. Sayangnya pihak perusahaan masih mendapat kesulitan untuk mendeteksi jumlah pokok sawit di tiap-tiap bloknya.

Berdasarkan permasalahan tersebut, untuk bisa mengetahui jumlah tanaman dalam tiap blok telah sesuai dengan standar pokok yang telah ditetapkan, maka perlu dilakukannya monitoring secara berkala melalui data spasial yang didapatkan dari fotogrametri melalui teknologi drone dan GPS (Global Positioning System) guna mengetahui perkembangan dan kondisi tanaman. Untuk analisis daerah lahan sawit pada skala perkebunan yang luas di Kabupaten Kutai Barat memungkinkan untuk dilakukannya dengan menggunakan GIS (Geographic Information System), karena dapat membantu untuk memetakan sebaran pokok sawit di dalam blok secara cepat dan akurat. Selain itu, perangkat ini mampu memvisualisasikan data-data spasial dalam format yang tepat, sehingga interpretasi data spasial menjadi mudah untuk dipahami (Prahasta, 2009). Dari paparan tersebut maka diharapkan sangat berguna dalam proses pengambilan keputusan sehingga dapat menjaga keberlangsungan produksi tanaman sesuai dengan standar yang telah ditetapkan.

\section{Bahan dan Metode}

Penelitian dilaksanakan di kebun kelapa sawit PT Ketapang Agro Lestari (First Resources Group) yang berada di wilayah Kecamatan Siluq Ngurai Kabupaten Kutai Barat Kalimantan Timur. Kegiatan analisis spasial dan pemetaan seluruhnya dilakukan di ruang GIS Kantor Kebun PT Ketapang Agro Lestari (First Resources Group). Penelitian telah dilaksanakan pada 03 September hingga 27 Oktober 2018. Alat dan bahan untuk penelitian ini terdiri atas GPS Garmin 64S, Laptop Core i7, DJI Phantom 4 Pro, Meteran, Bendera Pancang, Tongkat, parang, shapefile blok kebun PT Ketapang Agro Lestari, shapefile jalan, parit, dan terasan. Selain itu, adapun perangkat yang digunakan adalah ArcMap 10.3, Global Mapper, MapSource, DJI Phantom Go, DroneDeploy, dan Agisoft PhotoScan Professional. Penelitian ini dilaksanakan melalui beberapa tahapan-tahapan, yaitu : tahap persiapan, dimana pada tahap ini mempersiapkan kebutuhan yang diperlukan pada saat dilakukannya suatu pekerjaan, salahsatunya dalam kegiatan verifikasi sisip dan pokok antara lain peta sub-blok dan flight plan untuk rencana jalur terbang drone (Gambar 1 dan Gambar 2).

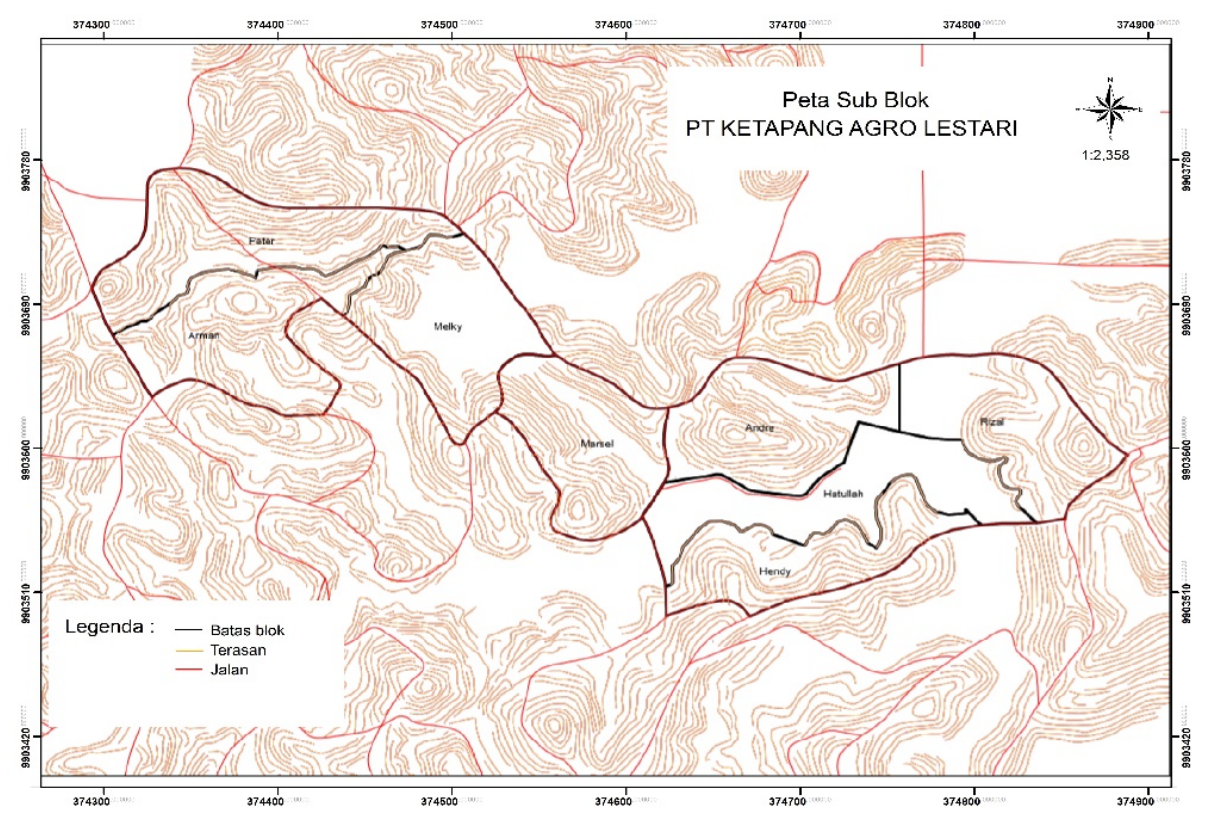

Gambar 1. Peta Sub Blok 


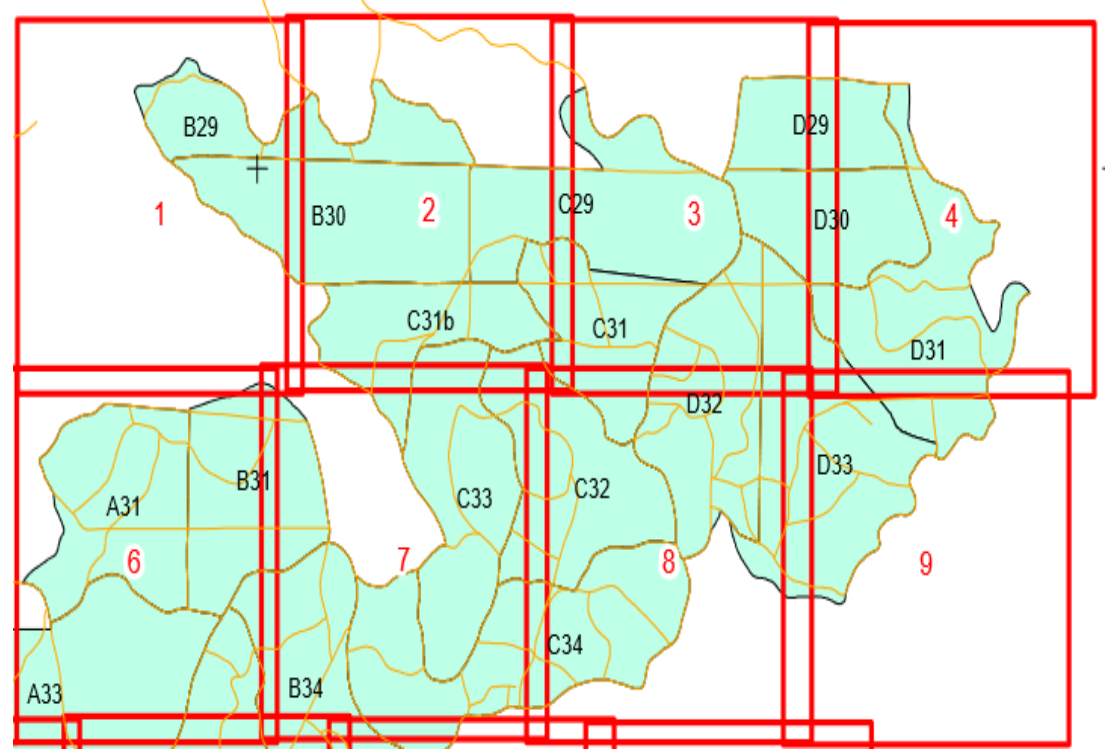

Gambar 2. Flight Plan

Tahap pengumpulan data, dimana pada tahap ini dilakukan pengumpulan data berupa foto udara yang diambil menggunakan drone, waypoint menggunakan GPS, serta data yang bersumber dari perusahaan PT Ketapang Agro Lestari berupa shapefile blok pada Afdeling I dan Afdeling IV, informasi luas blok, informasi tahun tanam, dan informasi pokok awal kelapa sawit yang masih hidup. Tahap pemrosesan data, dimana pada tahapan ini dilakukan dengan pendekatan mosaicking yaitu proses menggabungkan beberapa foto udar didasarkan pada kemiripan koordinat dan kemiripan objek. Pada tahap ini juga dilakukan proses konversi format waypoint dari GPX (GPS eXchange Format) ke dalam format shapefile menggunakan Global Mapper, sehingga dapat di add ke dalam ArcMap 10.3 yang berupa waypoint berwarna hitam, hijau dan merah yang menunjukkan pohon kelapa sawit yang masih hidup dan pohon kelapa sawit yang akan disisip.

Kemudian, hasil dari pendekatan mosaicking yang menghasilkan foto udara kebun dan hasil konversi waypoint, dioverlay menggunakan ArcMap 10.3 . Dari proses tersebut akan didapatkan perbedaan keakuratan dari foto udara menggunakan drone dengan waypoint menggunakan GPS dari segi geometric. Setelah diketahui perbedaan keakuratan, maka dilakukan koreksi orthorektifikasi untuk memperbaiki keadaannya dari segi geometric, sehingga dari hasil tersebut didapatkan Peta Verifikasi Sisip dan Pokok.

\section{Hasil dan Pembahasan}

\section{Faktor yang mendorong dilakukannya verifikasi sisip dan pokok}

Dalam perkebunan kelapa sawit, kondisi tanaman merupakan hal yang penting diperhatikan diantaranya jumlah tanaman dan tingkat kerapatan tanaman dalam blok. Apabila jumlah tanaman dan tingkat kerapatan tanaman dalam blok tidak sesuai dengan standar maka potensi produksi tidaklah maksimal. Untuk dilakukan penyisipan tanaman kelapa sawit sedini mungkin agar jarak pertumbuhan tanaman yang disisip dengan pokok kelapa sawit awal yang masih hidup tidak telalu jauh. Beberapa kreteria pokok sawit yang harus diganti untuk dilakukannya sisip antara lain pokok sawit mati atau sawit kerdil, pokok sawit yang terserang Ganoderma dan berat oleh Oryctes, serta pokok sawit yang unproductive (Sarana Informasi Pertanian, 2015).

Pokok kelapa sawit yang mati akan menyebabkan nilai SPH (Standar Pokok Perhektar) dalam blok tersebut menurun sehingga akan berdampak pada tingkat produksi yang akan dicapai. Untuk mengembalikan tingkat kerapatan dan jumlah pokok kelapa sawit maka dilakukan penyisipan 
dengan jarak tanam yang telah ditentukan oleh perusahaan PT Ketapang Agro Lestari (First Resources Group) yaitu $9 \mathrm{~m}$ x 7,79 m ; 9,20 m x 7,96 m ; dan 9,6 m x 8,3 m. Sehingga nantinya dengan jarak tersebut maka standar pokok perhektar di dalam blok adalah 143, 136 dan 125 pokok perhektar (SOP, 2012).

\section{Keadaan aktual berdasarkan data areal statement tahun 2018}

Hasil penelitian menunjukkan keadaan aktual pada Afdeling I dan Afdeling IV berdasarkan data areal statement 2018 adalah pada Afdeling I Blok B37 dengan tahun tanam pada 2012 memiliki luas tanam 20,28 ha, jumlah pokok kelapa sawit yang hidup adalah 2.090, sehingga didapatkan nilai SPH sebesar 103. Blok B38 dengan tahun tanam pada 2012 memiliki luas tanam 33,31 ha, jumlah pokok kelapa sawit yang hidup adalah 3.229, sehingga didapatkan nilai SPH sebesar 97. Blok B39 dengan tahun tanam pada 2012 memiliki luas tanam 34,61 ha, jumlah pokok kelapa sawit yang hidup adalah 2.840, sehingga didapatkan nilai SPH sebesar 82. Blok B40 dengan tahun tanam pada 2012 memiliki luas tanam 29,32 ha, jumlah pokok kelapa sawit yang hidup adalah 3.532, sehingga didapatkan nilai SPH sebesar 120. Blok D29 dengan tahun tanam pada 2015 memiliki luas tanam 10,02 ha, jumlah pokok kelapa sawit yang hidup adalah 296, sehingga didapatkan nilai SPH sebesar 30. Blok D30 dengan tahun tanam pada 2015 memiliki luas tanam 13,40 ha, jumlah pokok kelapa sawit yang hidup adalah 689, sehingga didapatkan nilai SPH sebesar 51.

Afdeling IV pada Blok A53a dengan tahun tanam pada 2014 memiliki luas tanam 27,07 ha, jumlah pokok kelapa sawit yang hidup adalah 918, sehingga didapatkan nilai SPH sebesar 34. Blok A55a dengan tahun tanam pada 2014 memiliki luas tanam 23,70 ha, jumlah pokok kelapa sawit yang hidup adalah 2.514, sehingga didapatkan nilai SPH sebesar 106. Blok C55 dengan tahun tanam pada 2013 memiliki luas tanam 18,16 ha, jumlah pokok kelapa sawit yang hidup adalah 1.898, sehingga didapatkan nilai SPH sebesar 105. Blok C56 dengan tahun tanam pada 2013 memiliki luas tanam 14,81 ha, jumlah pokok kelapa sawit yang hidup adalah 1.383, sehingga didapatkan nilai SPH sebesar 93. Blok D55 dengan tahun tanam pada 2013 memiliki luas tanam 2,44 ha, jumlah pokok kelapa sawit yang hidup adalah 163, sehingga didapatkan nilai SPH sebesar 67. Blok D56 dengan tahun tanam pada 2013 memiliki luas tanam 5,64 ha, jumlah pokok kelapa sawit yang hidup adalah 350, sehingga didapatkan nilai SPH sebesar 62. Blok D57 dengan tahun tanam pada 2018 memiliki luas tanam 26,47 ha, jumlah pokok kelapa sawit yang hidup adalah 1.741, sehingga didapatkan nilai SPH sebesar 66. Blok D59 dengan tahun tanam pada 2015 memiliki luas tanam 22,31 ha, jumlah pokok kelapa sawit yang hidup adalah 1.634, sehingga didapatkan nilai SPH sebesar 73.

Berdasarkan data areal statement 2018 (Tabel 1) didapatkan pada masing-masing blok di Afdeling I dan Afdeling IV bahwa nilai SPH tersebut belum mencapai standar yang telah ditetapkan. Stand pokok perhektare yang digunakan oleh perusahaan adalah dari 125-143 pokok (SOP, 2012). Menurut Pahan (2012) stand pokok perhektar (SPH) menunjukkan tingkat kerapatan tanam pohon kelapa sawit dalam blok, sehingga secara matematis dapat dihitung dengan rumus :

$$
\mathrm{SPH}=\frac{10.000 \mathrm{~m}^{2}}{\text { Jarak tanam antar pokok }(\mathrm{m}) \times \mathrm{Jarak} \text { tanam antar baris }(\mathrm{m})}
$$

Berdasarkan rumus di atas, untuk mengetahui SPH di dalam blok digunakan pada saat awal penanaman kelapa sawit dan untuk mengetahui SPH jika diliat dari jarak tanam yang digunakan. Adapun rumus untuk menentukan SPH, jika diketahui jumlah pokok tanaman dan luas blok yaitu :

$$
S P H=\frac{\text { Jumlah Pokok }}{\operatorname{Luas} \operatorname{Tanam}(h a)}
$$

\section{Verifikasi sisip dan pokok dengan waypoint dan fotogrametri}

Berdasarkan hasil tracking dan pengambilan foto udara, maka jumlah pokok kelapa sawit yang harus disisip pada masing-masing blok adalah pada Afdeling I Blok B37 dengan luas tanam 20,28 ha, jumlah pokok hidup 2.090 pokok, jumlah pokok kelapa sawit yang harus disisip adalah 462 pokok, sehingga dari data tersebut nilai SPH akhir yang didapatkan sebesar 126. 
Tabel 1. Keadaan aktual berdasarkan data areal statement 2018 (AFD : Afdeling; SPH : Stand Pokok Per hektare).

\begin{tabular}{rrrrrr}
\hline \hline \multirow{2}{*}{ Blok } & \multirow{2}{*}{ AFD } & \multicolumn{1}{c}{ Thn } & \multicolumn{2}{c}{ Data Areal Statement 2018 } \\
\cline { 4 - 6 } & & Tanam & Luas Tanam & Jumlah Pokok & SPH \\
\hline B37 & I & 2012 & 20,28 & 2.090 & 103 \\
B38 & I & 2012 & 33,31 & 3.229 & 97 \\
B39 & I & 2012 & 34,61 & 2.840 & 82 \\
B40 & I & 2012 & 29,32 & 3.532 & 120 \\
D29 & I & 2015 & 10,02 & 296 & 30 \\
D30 & I & 2015 & 13,40 & 689 & 51 \\
A53a & IV & 2014 & 27,07 & 918 & 34 \\
A55a & IV & 2014 & 23,70 & 2.514 & 106 \\
C55 & IV & 2013 & 18,16 & 1.898 & 105 \\
C56 & IV & 2013 & 14,81 & 1.383 & 93 \\
D55 & IV & 2013 & 2,44 & 163 & 67 \\
D56 & IV & 2013 & 5,64 & 350 & 62 \\
D57 & IV & 2018 & 26,47 & 1.741 & 66 \\
D59 & IV & 2015 & 22,31 & 1.634 & 73 \\
\hline
\end{tabular}

Blok B38 dengan luas tanam 33,31 ha, jumlah pokok hidup 3.229 pokok, jumlah pokok kelapa sawit yang harus disisip adalah 928 pokok, sehingga dari data tersebut nilai SPH akhir yang didapatkan sebesar 125. Blok B39 dengan luas tanam 34,61 ha, jumlah pokok hidup 2.840 pokok, jumlah pokok kelapa sawit yang harus disisip adalah 1.611 pokok, sehingga dari data tersebut nilai SPH akhir yang didapatkan sebesar 129. Blok B40 dengan luas tanam 29,32 ha, jumlah pokok hidup 3.532 pokok, jumlah pokok kelapa sawit yang harus disisip adalah 351 pokok, sehingga dari data tersebut nilai SPH akhir yang didapatkan sebesar 132. Blok D29 dengan luas tanam 10,02 ha, jumlah pokok hidup 296 pokok, jumlah pokok kelapa sawit yang harus disisip adalah 1.063 pokok, sehingga dari data tersebut nilai SPH akhir yang didapatkan sebesar 136. Blok D30 dengan luas tanam 13,40 ha, jumlah pokok hidup 689 pokok, jumlah pokok kelapa sawit yang harus disisip adalah 1.085 pokok, sehingga dari data tersebut nilai SPH akhir yang didapatkan sebesar 132.

Afdeling IV pada Blok A53a dengan luas tanam 27,07 ha, jumlah pokok hidup 918 pokok, jumlah pokok kelapa sawit yang harus disisip adalah 2.665 pokok, sehingga dari data tersebut nilai SPH akhir yang didapatkan sebesar 132. Blok A55a dengan luas tanam 23,70 ha, jumlah pokok hidup 2.514 pokok, jumlah pokok kelapa sawit yang harus disisip adalah 539 pokok, sehingga dari data tersebut nilai SPH akhir yang didapatkan sebesar 129. Blok C55 dengan luas tanam 18,16 ha, jumlah pokok hidup 1.898 pokok, jumlah pokok kelapa sawit yang harus disisip adalah 371 pokok, sehingga dari data tersebut nilai $\mathrm{SPH}$ akhir yang didapatkan sebesar 125. Blok C56 dengan luas tanam 14,81 ha, jumlah pokok hidup 1.383 pokok, jumlah pokok kelapa sawit yang harus disisip adalah 510 pokok, sehingga dari data tersebut nilai SPH akhir yang didapatkan sebesar 128. Blok D55 dengan luas tanam 2,44 ha, jumlah pokok hidup 163 pokok, jumlah pokok kelapa sawit yang harus disisip adalah 157 pokok, sehingga dari data tersebut nilai SPH akhir yang didapatkan sebesar 131. Blok D56 dengan luas tanam 5,64 ha, jumlah pokok hidup 350 pokok, jumlah pokok kelapa sawit yang harus disisip adalah 375 pokok, sehingga dari data tersebut nilai SPH akhir yang didapatkan sebesar 129. Blok D57 dengan luas tanam 26,47 ha, jumlah pokok hidup 1.741 pokok, jumlah pokok kelapa sawit yang harus disisip adalah 1.561 pokok, sehingga dari data tersebut nilai SPH akhir yang didapatkan sebesar 125. Blok D59 dengan luas tanam 22,31 ha, jumlah pokok hidup 1.634 pokok, jumlah pokok kelapa sawit yang harus disisip adalah 1.434 pokok, sehingga dari data tersebut nilai SPH akhir yang didapatkan sebesar 138. 
Berdasarkan data setelah dilakukan verifikasi sisip dan pokok 2018 (Tabel 2), maka didapatkan nilai SPH akhir pada masingmasing blok antara 125-138 pokok, dimana nilai tersebut sudah mencapai standar yang ditetapkan oleh perusahaan. Adapun persentase peningkatan SPH pada tiap-tiap bloknya, dimana pada Blok B37 sebesar 22,3\%, Blok
B38 sebesar 28,9 \%, Blok B39 sebesar 57,3\%, Blok B40 sebesar $10 \%$, Blok D29 sebesar $353,3 \%$, Blok D30 sebesar 158,8 \%, Blok A53a sebesar 288,2\%, Blok A55a sebesar 21,7 $\%$, C55 sebesar $19 \%$, C56 sebesar 37,6\%, D55 sebesar 95,5\%, D56 sebesar 108,1\%, D57 sebesar 89,4\% dan Blok D59 sebesar $89 \%$.

Tabel 2. Nilai SPH setelah dilakukan verifikasi sisip dan pokok 2018.

\begin{tabular}{|c|c|c|c|c|c|c|}
\hline \multirow{2}{*}{ Blok } & \multirow{2}{*}{ AFD } & \multicolumn{2}{|c|}{$\begin{array}{c}\text { Data Areal Statement } \\
2018\end{array}$} & \multirow{2}{*}{$\begin{array}{c}\text { Rencana } \\
\text { Tanam Sisip } \\
2018\end{array}$} & \multirow{2}{*}{$\begin{array}{l}\text { SPH } \\
\text { Akhir }\end{array}$} & \multirow{2}{*}{$\begin{array}{c}\% \\
\text { Peningkatan } \\
\text { SPH }\end{array}$} \\
\hline & & $\begin{array}{c}\text { Luas } \\
\text { Tanam }\end{array}$ & $\begin{array}{c}\text { Jumlah } \\
\text { Pokok Awal }\end{array}$ & & & \\
\hline B37 & I & 20,28 & 2.090 & 462 & 126 & 22.3 \\
\hline B38 & I & 33,31 & 3.229 & 928 & 125 & 28.9 \\
\hline B39 & I & 34,61 & 2.840 & 1.611 & 129 & 57.3 \\
\hline B40 & I & 29,32 & 3.532 & 351 & 132 & 10 \\
\hline D29 & I & 10,02 & 296 & 1.063 & 136 & 353.3 \\
\hline D30 & I & 13,40 & 689 & 1.085 & 132 & 158.8 \\
\hline A53a & IV & 27,07 & 918 & 2.665 & 132 & 288.2 \\
\hline A $55 a$ & IV & 23,70 & 2.514 & 539 & 129 & 21.7 \\
\hline C55 & IV & 18,16 & 1.898 & 371 & 125 & 19 \\
\hline C56 & IV & 14,81 & 1.383 & 510 & 128 & 37.6 \\
\hline D55 & IV & 2,44 & 163 & 157 & 131 & 95.5 \\
\hline D56 & IV & 5,64 & 350 & 375 & 129 & 108.1 \\
\hline D57 & IV & 26,47 & 1.741 & 1.561 & 125 & 89.4 \\
\hline D59 & IV & 22,31 & 1.634 & 1.434 & 138 & 89 \\
\hline
\end{tabular}

Pengaruh dan perbedaan waypoint dengan foto udara dalam kegiatan verifikasi sisip dan pokok

Berdasarkan hasil overlay menggunakan ArcMap 10.3 antara foto udara blok yang akan dilakukannya verifikasi sisip dan pokok dengan waypoint dari hasil tracking menggunakan GPS, maka didapatkan bahwa terdapat perbedaan dari segi keakuratan yang menandakan letak dan posisinya di muka bumi (Gambar 3). Waypoint memiliki keakuratan yang lebih tinggi dibandingkan dengan foto udara dikarenakan pengambilan waypoint dilakukan secara langsung di lapang yang menandakan letak dan posisi koordinatnya di muka bumi dengan tepat. Sedangkan pada foto udara masih memiliki kelemahan pada segi geometriknya dimana cukup sering terjadinya error (Purnomo, 2018). Geometrik menandakan ukuran, bentuk dan letak suatu objek dimuka bumi. Menurut Adi $e t$ al. (2017) yang menyatakan bahwa kesalahan geometric pada saat pengambilan foto udara terjadi akibat pengaruh dari topografi. Hal ini berbanding lurus dengan keadaan di perkebunan kelapa sawit PT Ketapang Agro Lestari (First Resources Group) dimana memiliki keadaan topografi yang relative cenderung datar-bergelombang hingga bergelombang-berbukit, selain itu dalam tiap bloknya keadaan topografi yang terbentang tidak ada yang mendominasi. Berdasarkan perbedaan yang telah diuraikan antara waypoint dengan foto udara, maka terdapat pengaruh yang cukup signifikan pada hasil overlay yaitu pada jarak waypoint sisip dengan objek kelapa sawit pokok awal yang masih hidup. Jarak yang berubah tersebut berpengaruh pada perencanaan pola tanam kelapa sawit di dalam blok. Sehingga dari permasalahan tersebut maka dilakukan orthorektifikasi dimana proses koresi geometric foto udara untuk memperbaiki kesalahan geometric akibat pengaruh dari topogarafi (Adi et al., 2017). 
Orthorektifikasi dilakukan agar orthofoto kembali pada posisi dan koordinat sebenarnya karena pada saat pengambilan data terjadi pergeseran (displacement) yang diakibatkan karena foto yang terlalu miring maupun karena variasi topografi (Gambar 4).

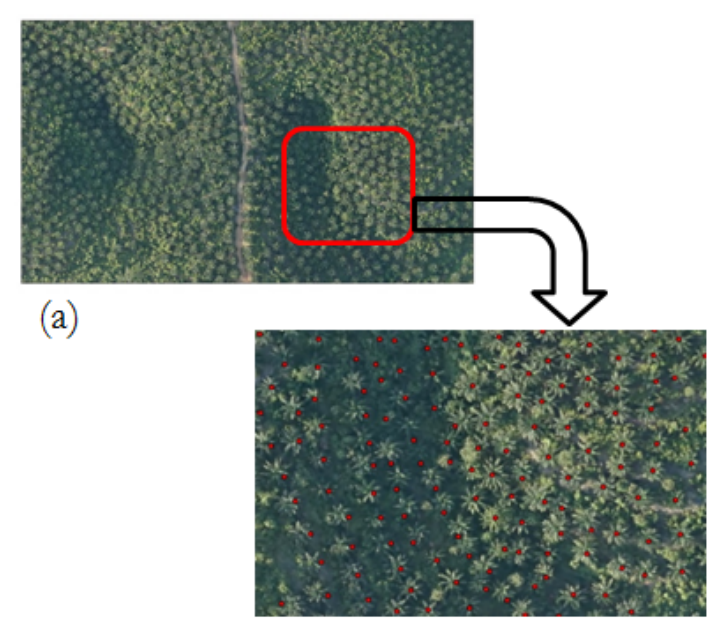

(b)

Gambar 3. Sebelum Orthorektifikasi

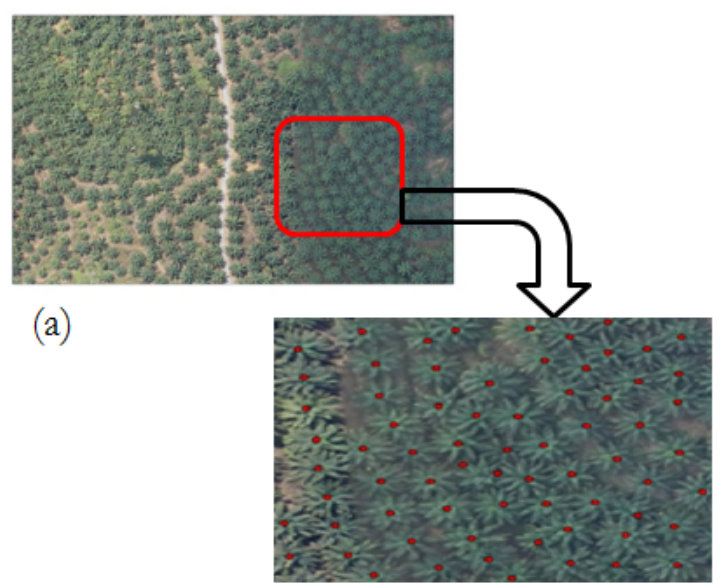

(b)

Gambar 4. Sesudah Orthorektifikasi

\section{Kesimpulan}

Waypoint menggunakan GPS memiliki keakuratan yang lebih tinggi dibandingkan dengan foto udara yang diambil menggunakan teknologi drone. Selain itu, terdapat pengaruh pada hasil overlay yaitu pada jarak waypoint rencana sisip dengan objek kelapa sawit pokok awal yang masih hidup. Jarak yang berubah akan berpengaruh pada perencaan pola tanam kelapa sawit di dalam blok. Sehingga dari permasalahan tersebut maka dilakukan orhtorektifikasi. GIS (Geographic Information System) dapat bermanfaat banyak dalam kegiatan ini, antara lain untuk pengolahan data hasil dari foto udara dan waypoint dari GPS, dan dapat mempercepat dalam kegiatan verifikasi sisip. Jumlah pokok sawit yang akan dilakukan sisip adalah pada Blok B37 sebanyak 462 pokok, Blok B38 sebanyak 928 pokok, Blok B39 sebanyak 1.611 pokok, Blok B40 sebanyak 351 pokok, Blok D29 sebanyak 1.063 pokok, Blok D30 sebanyak 1.085, Blok A53a sebanyak 2.665 pokok, Blok A55a sebanyak 539 pokok, Blok C55 sebanyak 371, Blok C56 sebanyak 510 pokok, Blok D55 sebanyak 157 pokok, Blok D56 sebanyak 375 pokok, Blok D57 sebanyak 1.561 dan Blok D59 sebanyak 1.431.

\section{Ucapan Terima Kasih}

Penulis pertama mengucapkan terima kasih kepada PT Ketapang Agro Lestari (First Resources Group) yang telah memberikan kesempatan kepada penulis pertama untuk ikut dalam kegiatan project verifikasi sisip dan pokok pada perkebunan kelapa sawit PT Ketapang Agro Lestari (First Resources Gorup).

\section{Daftar Pustaka}

Adi, A.P., Prasetyo, Y. dan Yuwono, B.D. 2017. Pengujian akurasi dan ketelitian planimetrik pada pemetaan bidang tanah pemukiman skala besar menggunakan wahana Unmanned Aerial Vehicle (UAV). Jurnal Geodesi Undip 6 (1) : 2018-217.

Pahan, I. 2012. Panduan Lengkap Kelapa Sawit. Penebar Swadaya, Jakarta.

Prahasta, E. 2009. Sistem Informasi Geografis Konsep-Konsep Dasar (Perspektif Geodesi \& Geomatika. Bandung: Informatika. Hal 150-151

Purnomo, L. 2018. Penggunaan Drone Untuk Pemetaan. Diakses melalui https://www.liupurnomo.com pada tanggal 17 Januari 2019 pukul 11:34

Sarana Informasi Pertanian. 2015. Penyisipan Tanaman Kelapa Sawit. Diakses melalui https:/ / tangkaikayu.com/penyisipan-tanamankelapa-sawit/ pada tanggal 31 Januari 2019 pukul 18:48

Sugianto, 2010. Sistem Informasi Geografis Untuk Pemetaan dan Analisa Daerah Pertanian Di 
Jurnal Tanah dan Sumberdaya Lahan Vol 6 No 2 : 1333-1340, 2019

e-ISSN:2549-9793, doi: 10.21774/ub.jts1.2019.006.2.14

Kabupaten Ponorogo. Insititut Teknologi Sepuluh Nopember Surabaya: jurusan Teknologi Informasi.

Tim Penyusun SOP. 2012. Sensus Pokok dan Produksi. PT Ketapang Agro Lestari (First Resources Group). 